\title{
IMPLEMENTASI DAN ANALISIS GAP STANDAR KACA PENGAMAN KERETA
}

\author{
Implementation and Gap Analysis of Standard Safety Glass for Train \\ Ratih Resti Astari, Nurhidayati dan Karlina Noordiningsih \\ Balai Besar Keramik, Jl. Jend. A. Yani 392, Bandung 40272 \\ Email : ratihresti@gmail.com
}

\begin{abstract}
Abstrak
Kereta api merupakan moda transportasi yang banyak digunakan di Indonesia. Kasus pelemparan kaca jendela kereta yang mengakibatkan penumpang cedera banyak terjadi akhir-akhir ini. Hal ini membutuhkan perhatian, terutama karena berkaitan dengan jaminan keselamatan dan keamanan bagi pengguna kereta api. Selain pada oknum yang melakukan, perhatian mengenai permasalahan ini juga harus difokuskan pada aspek penting lainnya yaitu pada kaca jendela yang digunakan. Standar kaca pengaman kereta telah diterapkan di Jepang dan Eropa, hal ini merupakan salah satu jaminan keselamatan dan keamanan pengguna kereta api. Indonesia telah mempunyai standar kaca pengaman untuk kendaraan bermotor yang dapat dirujuk sebagai pembanding dalam penyusunan standar kaca pengaman kereta api. Dengan metode analisis gap akan dibandingkan standar kaca pengaman kereta yang telah diterapkan di Jepang dan Eropa serta standar kaca pengaman bermotor sebagai pembanding. Selain itu peraturan perkeretaapian yang berlaku di Indonesia juga digunakan sebagai dasar untuk menentukan parameter syarat mutu. Dari hasil kajian ini maka parameter syarat mutu tersebut dapat digunakan sebagai rekomendasi dalam penyusunan standar kaca pengaman kereta api.
\end{abstract}

Kata kunci: kaca pengaman, kereta api, analisis gap

\begin{abstract}
Trains, one of the transportation modes that is widely used in Indonesia. Recently, the cases of stone throwing to the train windows have caused many injured passengers. This cases required attention, especially as it related to the safety and security guarantees for the train user. Not only on the perpetrators, but the attention also shall be focused on the another main aspect, train glass windows. The standard of safety glass for railing stock has been implemented in Japan and Europe, it is one of the safety and security guarantees of railway users. Indonesia has had a standard of safety glass for wheeled vehicle that can be referred as comparators in the arrangement of the standard safety glass for train. The gap analysis method will be conducted by compare standard of the safety glass for railing stock that has been applied in Japan and Europe with SNI of safety glass for wheeled vehicle. In addition, the railway regulations that applied in Indonesia are also used as the basis in order to determine the quality requirement parameters. From this studied, the quality requirement parameters could be used as a recommendation in the arrangement of the standard safety glass for train.
\end{abstract}

Keywords: safety glass, train, gap analysis

\section{PENDAHULUAN}

Kereta api merupakan salah satu sarana transportasi umum yang banyak digunakan di Indonesia. Berdasarkan data dari BPS, tercatat jumlah penumpang kereta api hingga akhir tahun 2018 adalah 42,2 juta penumpang dari seluruh kereta api yang beroperasi di daerah Sumatra dan Jawa (Jabodetabek dan Non Jabodetabek). Jumlah penumpang kereta api cenderung mengalami peningkatan dari tahun ke tahun. Jika dibandingkan dengan tahun 2017, peningkatan jumlah penumpang pada tahun 2018 meningkat sebesar 7,3\% (Badan Pusat Statistik, 2017). Penyebab tingginya animo masyarakat untuk menggunakan kereta api sebagai sarana transportasi antara lain karena harga tiket yang relatif ekonomis dan bebas dari kemacetan, sehingga lebih efisien jika dibandingkan dengan moda transportasi lain (Pramyastiwi, Hardjanto, \& Said, 2013). Tingginya penggunaan kereta api di Indonesia juga harus diikuti dengan peningkatan pelayanan dan jaminan keselamatan pengguna kereta api. Jaminan keselamatan penumpang merupakan fokus penting yang harus diutamakan.

Kecelakaan kereta api sering terjadi, berdasarkan laporan dari KNKT (Komite Nasional Keselamatan Transportasi) pada tahun 2018 telah terjadi beberapa kali kecelakaan akibat kereta anjlok, rel patah, patahnya pantograph, dan lain-lain. Penyebab kecelakaan kereta api dapat bersumber dari beberapa faktor yaitu manusia, alam, sarana dan prasarana (Yustikasari, 2011). Salah satu sarana dan prasarana kereta api yang juga 
membutuhkan perhatian khusus yaitu kaca jendela. Kaca jendela selain memenuhi fungsi untuk melihat pemandangan juga harus memenuhi persyaratan keselamatan dan keamanan. Salah satu masalah yang dapat mengganggu keselamatan penumpang adalah tindakan pengrusakan kaca jendela dengan pelemparan batu oleh oknum yang tidak bertanggungjawab. Seperti yang telah terjadi di DAOP 3 Cirebon sebanyak 28 pelemparan batu pada periode Januari - Juni 2018 (Okenews, 2018) dan pada Maret 2017 di DAOP 2 Bandung terjadi pelemparan dari supporter bola yang menyebabkan 20 kaca rusak sehingga terdapat 3 korban luka pengguna jasa Kereta Api Serayu (Republika, 2017).

Selain dari kurangnya kesadaran masyarakat, hal ini juga terkait dengan jenis kaca yang digunakan pada gerbong dan lokomotif kereta. Peraturan mengenai kaca yang digunakan untuk lokomotif telah diatur dalam Peraturan Menteri Perhubungan Nomor KM. 44 Tahun 2010, Standar Spesifikasi Teknis Peralatan Khusus yaitu kaca depan pada kabin masinis yang bebas pandang, mampu menahan benturan dan apabila pecah tidak membahayakan awak sarana perkeretaapian. Spesifikasi teknis tersebut adalah persyaratan umum dan kinerja yang merupakan ketentuan teknis sarana perkeretaapian dan tidak mengatur mengenai persyaratan mutunya. Di dalam PM 175 Tahun 2015, Standar Spesifikasi Teknis Kereta Kecepatan Norma dengan Penggerak Sendiri, telah mengatur bahwa jendela kaca yang Terdapat berbagai jenis kaca dengan tujuan penggunaan yang berbeda pula. Indonesia telah mempunyai SNI 8210:2018, Kaca pengaman untuk kendaraan bermotor, SNI ISO 12540:2017, Kaca untuk bangunan - Kaca pengaman soda kapur silikat diperkeras, dan SNI ISO 12543 Bagian 1 - 4 yang merupakan seri metode uji kaca untuk bangunan - kaca berlapis dan kaca pengaman berlapis. Penggunaan kaca pengaman untuk bangunan dan kendaraan telah umum digunakan. Jika merujuk pada JIS 3213:2018, definisi kaca pengaman adalah produk kaca lembaran yang telah diproses untuk tujuan mengurangi cedera yang disebabkan oleh rusaknya kaca jendela kereta akibat kecelakaan, dengan istilah yang umum adalah adalah kaca pengaman diperkeras (tempered safety glass), kaca pengaman berlapis (laminated safety glass) dan kaca pengaman isolasi (sealed insulating safety glass). Dari hal tersebut dapat diketahui bahwa kaca lembaran biasa dengan jenis kaca pengaman sangat berbeda.
Dengan adanya standar kaca pengaman untuk kereta api tentu diharapkan dapat menjadi salah satu langkah jaminan keselamatan bagi penumpang kereta api. SNI mengenai kaca pengaman untuk kereta api hingga saat ini belum ditetapkan dan penelitian yang mempublikasi mengenai standar kaca pengaman kereta api juga belum pernah dilakukan. Penelitian mengenai kereta api yang telah dilakukan antara lain pemantauan jalur dan sarana dengan GPS (Yulius, 2012), analisis kinerja operasi kereta api (Sumantri, 2014), perkembangan kualitas pelayanan perkeretaapian (Pramsyatiwi, 2013), dan lainlain. Kajian ini bertujuan untuk mengetahui implementasi standar kaca pengaman untuk kereta yang telah dilakukan oleh negara lain sehingga dapat digunakan sebagai rekomendasi untuk penyusunan standar kaca pengaman untuk kereta api di Indonesia.

\section{TINJAUAN PUSTAKA}

Kaca lembaran merupakan bahan baku dari kaca pengaman yang diproses lagi. Berdasarkan SNI 47:2018, Kaca lembaran, komponen utama (persen fraksi massa) yang harus dimiliki oleh kaca lembaran adalah sebagai berikut:

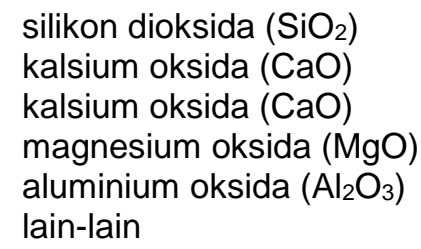

Kaca pengaman dapat dibedakan menjadi 3 jenis yaitu :

1. Kaca pengaman diperkeras

kaca yang telah diolah menjadi kaca pengaman dengan suatu proses pemberian pra tegangan, sehingga apabila pecah akan berhamburan menjadi butiran-butiran kecil. Pemberian pra tegangan bertujuan untuk menambah ketahanan kaca terhadap pengaruh gaya-gaya dari luar dan perubahan suhu. Pemberian pra tegangan ini diberikan merata pada seluruh permukaan kecuali ditentukan lain. Bentuk kaca pengaman ini dapat rata maupun lengkung. Pemberian pra tegangan dapat dilakukan dengan pemanasan kemudian didinginkan cepat.

2. Kaca pengaman berlapis Kaca pengaman yang terdiri dari dua lembar kaca atau lebih yang direkatkan satu sama lain dengan menggunakan satu atau lebih lapisan plastik (polyvinyl butiral film) yang tembus pandang baik berwarna atau tidak, 
yang apabila pecah, pecahannya akan tetap melekat pada lapisan plastik tersebut.

3. Kaca pengaman isolasi

Kaca dengan bagian keliling yang tersegel, terdiri dari dua atau lebih lapis kaca baik kaca berlapis atau kaca diperkeras yang ditempatkan secara paralel dan dipisahkan oleh ruang uniform yang diisi dengan udara yang hampir sama dengan tekanan atmosferik eksternal.

\section{METODE PENELITIAN}

Metode analisis yang digunakan dalam kajian ini adalah analisis deskriptif berupa analisis gap. Analisis gap digunakan untuk melihat perbandingan standar yang telah ada sebelumnya sehingga dapat menjadi acuan dan rekomendasi untuk penyusunan SNI Kaca pengaman untuk kereta api. Dari analisis gap tersebut dapat diperoleh parameter-parameter yang dapat digunakan sebagai rekomendasi dalam syarat mutu SNI Kaca pengaman untuk kereta api. Analisis gap dilakukan dengan membandingkan standar-standar sebagai berikut :

1. JIS 3213:2018, Safety glass for railway rolling stock

2. BS EN 15152:2007, Railway appications Front windscreens for train cabs

3. SNI 8210:2018, Kaca pengaman untuk kendaraan bermotor

Setelah dilakukan perbandingan standar, juga akan ditunjukkan berbagai peraturan perkeretaapian yang berlaku di Indonesia sehingga selain dari perbandingan standar juga akan dilihat urgensi standar kereta api dari sudut pandang peraturan yang telah berlaku di Indonesia. Pada Gambar 1 menampilkan alur kajian yang dilakukan.

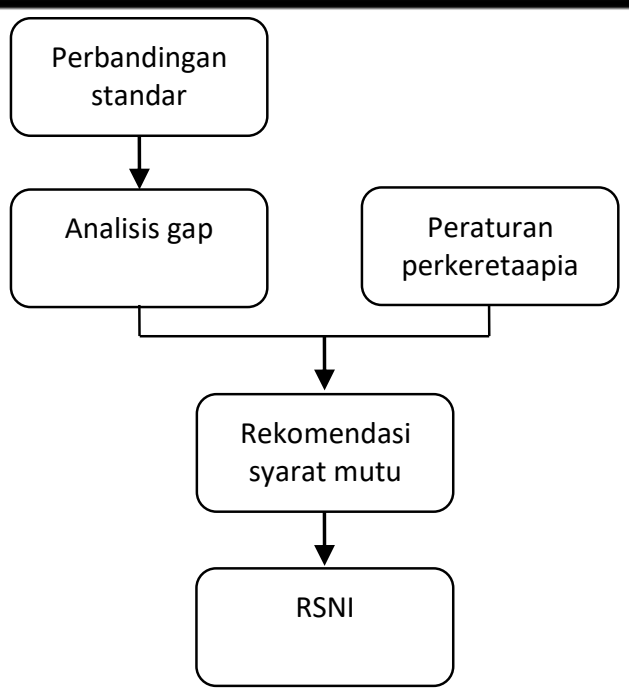

Gambar 1. Alur kajian standar kaca pengaman kereta api

\section{HASIL DAN PEMBAHASAN}

Analisis gap berdasarkan paramater syarat mutu yang tercantum dalam masingmasing standar. JIS 3213:2018 merupakan standar yang mengatur mengenai standar kaca pengaman untuk sarana kereta api. Sedangkan BS EN 15152:2007 menetapkan persyaratan fungsional untuk kaca depan ruang masinis kereta dengan kecepatan tinggi. Dan SNI 8210:2018 merupakan standar kaca pengaman untuk kendaraan bermotor yang dapat digunakan sebagai pembanding karena dianggap mempunyai parameter syarat mutu yang mirip dengan kaca pengamanan untuk kereta api. Di dalam Tabel 1 tercantum perbandingan antara standar JIS 3213:2018, BS EN 15152:2007 dan SNI 8210:2018.

Tabel 1- Perbandingan Standar Kereta Api dan Kendaraan Bermotor

\begin{tabular}{|c|c|c|c|c|c|c|c|c|c|}
\hline \multirow{2}{*}{ No } & \multirow{2}{*}{ Syarat Mutu } & \multicolumn{3}{|c|}{ JIS R 3213:2018 } & \multirow[t]{2}{*}{$\begin{array}{c}\text { BS EN } \\
15152: 2007 \\
\end{array}$} & \multicolumn{4}{|c|}{ SNI 8210:2018 } \\
\hline & & $\mathbf{T}$ & $\mathbf{L}$ & I & & TW & TP & LW & LP \\
\hline 1 & Dimensi & $\mathrm{V}$ & $\mathrm{V}$ & $\mathrm{V}$ & - & - & - & - & - \\
\hline 2 & Warp/kerataan & $\mathrm{V}$ & $\mathrm{v}$ & $\mathrm{V}$ & - & - & - & - & - \\
\hline 3 & $\begin{array}{l}\text { Bent error } \\
\text { (kelengkungan) }\end{array}$ & $\mathrm{V}$ & $\mathrm{V}$ & $\mathrm{v}$ & - & - & - & - & - \\
\hline 4 & Sifat tampak & $\mathrm{V}$ & $\mathrm{V}$ & - & $\mathrm{V}$ & $\mathrm{V}$ & $\mathrm{V}$ & $\mathrm{V}$ & $\mathrm{V}$ \\
\hline 5 & Transmisi cahaya & - & $\mathrm{V}$ & - & - & $\mathrm{v}$ & $\mathrm{V}$ & $\mathrm{V}$ & $\mathrm{V}$ \\
\hline 6 & Distorsi optik & - & $\mathrm{V}$ & - & - & $\mathrm{V}$ & $\mathrm{V}$ & $\mathrm{V}$ & $\mathrm{V}$ \\
\hline 7 & Ketahanan suhu tinggi & - & $\mathrm{V}$ & - & - & - & - & v & $\mathrm{V}$ \\
\hline 8 & Ketahanan bentur & v & $\mathrm{V}$ & - & $\mathrm{v}$ & V & $\mathrm{V}$ & $\mathrm{v}$ & $\mathrm{V}$ \\
\hline 9 & $\begin{array}{l}\text { Ketahanan benturan } \\
\text { kepala boneka uji } \\
\text { (manikin) }\end{array}$ & - & - & - & - & V & - & v & - \\
\hline 10 & Fragmentasi & $\mathrm{v}$ & - & - & - & $\mathrm{V}$ & $\mathrm{V}$ & - & - \\
\hline
\end{tabular}




\begin{tabular}{|c|c|c|c|c|c|c|c|c|c|}
\hline \multirow{2}{*}{ No } & \multirow{2}{*}{ Syarat Mutu } & \multicolumn{3}{|c|}{ JIS R 3213:2018 } & \multirow[t]{2}{*}{$\begin{array}{c}\text { BS EN } \\
15152: 2007 \\
\end{array}$} & \multicolumn{4}{|c|}{ SNI 8210:2018 } \\
\hline & & $T$ & $\mathbf{L}$ & I & & TW & TP & LW & LP \\
\hline 11 & Abrasi & - & - & - & $\mathrm{v}$ & - & - & $\mathrm{v}$ & $\mathrm{v}$ \\
\hline 12 & Ketahanan radiasi & - & - & - & - & - & & $\mathrm{v}$ & $\mathrm{v}$ \\
\hline 13 & Ketahanan kelembaban & - & - & - & - & - & - & $\mathrm{v}$ & $\mathrm{v}$ \\
\hline 14 & Secondary image & - & - & - & $\mathrm{v}$ & $\mathrm{v}$ & $\mathrm{v}$ & $\mathrm{v}$ & - \\
\hline 15 & Titik embun & - & - & $\mathrm{V}$ & - & - & - & - & - \\
\hline 16 & $\begin{array}{l}\text { Daya tahan terhadap } \\
\text { percepatan }\end{array}$ & - & - & $\mathrm{v}$ & - & - & - & - & - \\
\hline 17 & Karakteristik termal & - & - & $\mathrm{v}$ & - & - & - & - & - \\
\hline 18 & Penghamburan cahaya & - & - & - & $\mathrm{V}$ & - & - & - & - \\
\hline 19 & Kromatisitas & - & - & - & $\mathrm{v}$ & - & - & - & - \\
\hline 20 & $\begin{array}{l}\text { Visibilitas sisa setelah } \\
\text { pecah }\end{array}$ & - & - & - & $\mathrm{v}$ & - & - & - & - \\
\hline 21 & Spalling & - & - & - & $\mathrm{v}$ & - & - & - & - \\
\hline 22 & Ketahanan terhadap api & - & - & - & $\mathrm{v}$ & - & - & - & - \\
\hline 23 & $\begin{array}{l}\text { Ketahanan terhadap } \\
\text { benturan berulang dari } \\
\text { partikel kecil (gravelling) }\end{array}$ & - & - & - & $\mathrm{v}$ & - & - & - & - \\
\hline \multicolumn{10}{|c|}{ Keterangan: } \\
\hline $\mathrm{T}$ & \multicolumn{9}{|c|}{$=$ Tempered safety glass / kaca pengaman diperkeras } \\
\hline $\mathrm{L}$ & \multicolumn{9}{|c|}{$=$ Laminated safety glass / kaca pengaman berlapis } \\
\hline I & \multicolumn{9}{|c|}{$=$ Insulating safety glass / kaca pengaman isolasi } \\
\hline TW & \multicolumn{9}{|c|}{$=$ Tempered safety glass for windscreen / kaca pengaman diperkeras untuk kaca depan } \\
\hline TP & \multicolumn{9}{|c|}{$=$ Tempered safety glass for panel/ kaca pengaman diperkeras untuk kaca panel } \\
\hline LW & \multicolumn{9}{|c|}{$=$ Laminated safety glass for windscreen / kaca pengaman berlapis untuk kaca depan } \\
\hline LP & \multicolumn{9}{|c|}{$=$ Laminated safety glass for panel / kaca pengaman diperkeras untuk kaca panel } \\
\hline
\end{tabular}

Berdasarkan Tabel 1 maka analisis gap mengenai masing-masing standar tersebut adalah sebagai berikut:

\section{JIS R 3213:2018}

Di dalam standar ini terdapat 3 jenis kaca pengaman yaitu kaca pengaman berlapis, kaca pengaman diperkeras dan kaca pengaman isolasi. Masing-masing jenis kaca pengaman tersebut mempunyai syarat mutu yang berbeda. Terdapat parameter syarat mutu yang digunakan pada ketiga jenis kaca pengaman tersebut namun juga terdapat uji yang khusus untuk masingmasing kaca. Pada kaca diperkeras harus dilakukan uji fragmentasi, yaitu uji pemecahan kaca menggunakan palu khusus dan jumlah pecahan kaca pada luas bidang tertentu harus sesuai syarat mutu. Sedangkan pada kaca berlapis syarat mutu transmisi cahaya, distorsi optik dan ketahanan suhu tinggi wajib dilakukan. Untuk uji ketahanan benturan dilakukan pada kaca pengaman diperkeras dan berlapis dengan syarat mutu yang berbeda. Uji ketahanan bentur yang dilakukan pada standar ini mirip dengan uji bentur pada SNI 8210:2018, yaitu menggunakan bola baja yang dijatuhkan dari ketinggian tertentu secara bebas sehingga membentur kaca pengaman yang berada horizontal di bawah.
Yang membedakan dengan SNI 8210:2018 adalah massa bola baja dan ketinggiannya. Pada kaca pengaman isolasi, syarat mutu yang harus digunakan adalah titik embun, daya tahan terhadap percepatan dan karakteristik termal.

\section{BS EN 15152:2007}

Standar ini menetapkan persyaratan fungsional untuk kaca depan ruang masinis pada kereta dengan kecepatan tinggi. Terdapat syarat mutu yang berbeda dengan JIS R 3213:2018, yaitu adanya syarat mutu abrasi, secondary image, penghamburan cahaya, kromatisitas, visibilitas setelah pecah, spalling, ketahanan terhadap api dan ketahanan terhadap benturan berulang dari partikel kecil (gravelling). Syarat mutu ketahanan bentur juga terdapat pada standar ini, namun mempunyai metode yang berbeda dengan JIS R3213:2018 maupun dengan SNI 8210:2018. Uji ketahanan bentur yang digunakan dalam standar ini yaitu menggunakan proyektil yang ditembakkan dengan kecepatan tertentu.

\section{SNI $8210: 2018$}

Standar ini meliputi kaca pengaman berlapis dan kaca pengaman diperkeras untuk kendaraan bermotor yang digunakan untuk instalasi kaca depan atau kaca panel atau 
sebagai partisi pada kendaraan kategori $L$, M, N, O dan T. Standar ini juga mengacu pada regulasi kendaraan bermotor Eropa, yaitu Addendum 42: Regulation No. 43 Revision 3, ECE/TRANS/505/Rev.1/ Add.42/Rev.3. SNI ini membedakan syarat mutu antara kaca depan dan kaca panel serta kaca pengaman berlapis dan diperkeras. Beberapa persyaratan mutu yang tidak terdapat di standar sebelumnya adalah ketahanan benturan kepala boneka uji (manikin), ketahanan radiasi dan ketahanan kelembaban. Uji ketahanan benturan kepala boneka uji (manikin) hanya berlaku untuk kaca depan pengaman berlapis maupun diperkeras. Syarat mutu fragmentasi sedikit berbeda dengan JIS 3213:2018 yang persyaratan mutu jumlah fragmennya berdasarkan tebal kaca sedangkan pada SNI ini, jumlah fragmen berdasarkan pada zona kaca yang telah ditentukan dalam standar ini.

Tabel 2 - Peraturan Perkeretaapian

\begin{tabular}{|c|c|c|}
\hline No & Peraturan & Pernyataan \\
\hline & PM 175 Tahun 2015 & $\begin{array}{l}\text { Pasal } 16 \\
\text { - Bagian atas pintu dipasang kaca dari jenis safety glass. } \\
\text { - Kaca pintu mampu menahan benturan sesuai dengan ketentuan } \\
\text { yang dipersyaratkan pada Standar Nasional Indonesia (SNI). } \\
\text { Pasal } 25 \\
\text { Kabin masinis sebagaimana dimaksud pada ayat } 1 \text {, harus memenuhi } \\
\text { persyaratan } \\
\text { - memiliki ruang bebas pandang ke depan pada saat } \\
\text { dioperasikan } \\
\text { kaca depan kabin mampu menahan benturan sesuai dengan } \\
\text { ketentuan yang dipersyaratkan pada Standar Nasional } \\
\text { Indonesia (SNI) untuk kendaraan bermotor atau standar lain } \\
\text { yang setara }\end{array}$ \\
\hline
\end{tabular}

$2 \quad$ PM 24 Tahun $2015 \quad$ Pasal 45

(1) Palu pemecah kaca sebagaimana dimaksud pada Pasal 43 sekurang-kurangnya 4 unit (2 di sisi kiri dan 2 di sisi kanan) ditempatkan berdekatan dengan jendela darurat jenis yang tidak bisa dibuka-tutup yang dipasang kaca jendela dari jenis safety glass dan dilaminasi untuk setiap ruang penumpang

(2) Pengecualian terhadap pemasangan palu pemecah kaca sebagaimana dimaksud pada ayat (1) dapat dilakukan untuk jendela darurat yang dapat dibuka-tutup dengan persyaratan sekurang-kurangnya dapat dilalui oleh tubuh orang dewasa dengan mudah.

$3 \quad$ PP No. 72 Tahun $2009 \quad$ Pasal 35

Pengaturan perjalanan kereta api dilakukan dengan semboyan berupa:

a. isyarat dari petugas pengatur perjalanan kereta api;

b. sinyal;

c. tanda; atau

d. marka

\begin{tabular}{lll}
\hline 4 & PM 153 Tahun 2016 & Pasal 19 \\
& Kabin masinis harus memenuhi persyaratan: \\
& - memiliki ruang bebas pandang ke depan pada saat dioperasikan \\
& - kaca depan kabin mampu menahan benturan yang disyaratkan \\
& sesuai dengan ketentuan Standar Perkeretaapian \\
& \\
\hline 5 & PM 47 Tahun 2011 & Jendela berfungsi sebagai penerangan pada siang hari, sehingga \\
& tingkat kegelapan jendela maksimal adalah 40\% dan dilengkapi dengan \\
& 6 jendela darurat yang dapat dibuka atau dapat dipecahkan dan diberi \\
& tanda.
\end{tabular}

Jika dilihat dari kebutuhan standar kaca pengaman untuk kereta api, maka beberapa syarat mutu yang menyangkut keselamatan penumpang dan masinis sangat penting. Dengan menyesuaikan kondisi di Indonesia, standar syarat mutu kaca pengaman harus 
dapat mengakomodir segala kebutuhan. Jika dilihat dari kasus pelemparan kaca yang sering terjadi maka kaca yang digunakan di jendela maupun di pintu kereta api harus memenuhi syarat minimum dalam kaca pengaman. Dengan penggunaan kaca pengaman diharapkan dapat meminimalisir resiko tersebut. Berdasarkan SNI 8210:2018 menyatakan bahwa peruntukan kaca pengaman diperkeras sebagai kaca depan hanya untuk kendaraan dengan kecepatan kurang dari 40 kilometer per jam. Sehingga penggunaan kaca pengaman berlapis untuk kaca depan kendaraan bermotor sebaiknya diterapkan. Hal ini menyangkut keamanan dan keselamatan pengemudi maupun penumpang dikarenakan kaca pengaman berlapis apabila pecah maka pecahan kacanya masih menempel pada lapisan plastik yang berada di antara kaca tersebut dan benda yang dilempar tidak tembus atau masih tertahan pada kaca tersebut. Sehingga kaca pengaman berlapis sangat baik digunakan sebagai kaca depan. Kaca pengaman diperkeras jika pecah maka pecahannya berupa butiran kecil yang tidak membahayakan penumpang. Selain merujuk pada standar yang berlaku, syarat mutu juga harus memperhatikan peraturan yang berlaku. Tabel 2 menyajikan ringkasan dari peraturan syarat spesifikasi teknis kereta yang berlaku. Dari Tabel 2, kabin masinis harus memiliki ruang bebas pandang ke depan pada saat dioperasikan. Hal ini berkaitan juga dengan pengaturan perjalanan kereta api yang menggunakan sinyal, tanda atau marka. Masinis harus dapat melihat sinyal, tanda atau marka melalui kaca depan lokomotif. Selain itu fungsi jendela sebagai penerangan pada siang hari dengan tingkat kegelapan maksimal $40 \%$ juga termasuk dalam persyaratan minimum terkait keperluan visual pengguna kereta yang harus tercantum dalam standar kereta api. Seperti pada kasus kecelakaan yang terjadi di DAOP I Jakarta, yaitu tumburan kereta antara KRL 1154 dan KRL 1156. Terdapat 2 rekomendasi yang diberikan oleh KNKT yang berkaitan dengan kebutuhan ruang bebas pandang masinis yaitu:

- Melepaskan ram pengaman pada kaca depan kabin masinis KRL dan agar selalu menggunakan laminated safety glass demi keselamatan awak sarana, mengacu PM. 24 Tahun 2015 tentang Standar Keselamatan Perkeretaapian dan PM. 175 Tahun 2015 tentang Standar Spesifikasi Kereta Kecepatan Normal dengan Penggerak Sendiri.

- Melepaskan atau memodifikasi penghalang sinar matahari dan papan rute sehingga tidak mengurangi ruang bebas pandang ke depan awak sarana KRL.

Untuk menghindari kasus seperti di atas maka persyaratan visual harus ditetapkan dalam SNI.

Persyaratan mekanik seperti kaca depan harus mampu menahan benturan dan jendela darurat yang dapat dibuka atau dipecahkan merupakan persyaratan minimum yang harus dimiliki oleh kaca pengaman kereta api. Namun pada PM 24 Tahun 2015, mengenai Standar Keselamatan Perkeretaapian, Pasal 45, disebutkan bahwa untuk ketentuan pengamanan dan keselamatan harus disediakan palu pemecah yang ditempatkan berdekatan dengan jendela darurat jenis yang tidak bisa dibuka-tutup yang dipasang kaca jendela dari jenis safety glass dan dilaminasi untuk setiap ruang penumpang. Hal ini dapat diinterpretasikan sebagai penggunaan kaca pengamanan berlapis (laminated safety glass) pada gerbong penumpang sebagai jendela darurat. Hal ini tentu tidak sesuai dengan karakteristik kaca pengaman berlapis yang sukar dipecahkan karena adanya lapisan plastik/polimer di antar lapisan kacanya. Untuk jendela darurat yang mudah dipecahkan dengan palu pemecah, direkomendasikan untuk menggunakan kaca pengaman diperkeras (tempered safety glass). Pada SNI 8210 dan JIS 3213, telah menetapkan syarat mutu fragmentasi kaca pengaman diperkeras namun tidak berlaku untuk kaca pengaman berlapis. Sedangkan Pengujian fragmentasi tersebut dilakukan menggunakan palu yang ditekankan pada kaca pengaman diperkeras kemudian pecahan kaca akibat penekanan palu dihitung dan harus memenuhi persyaratan mutu. Di dalam JIS 3213, syarat mutu fragmentasi dibedakan berdasarkan tebal kaca yaitu tebal 3,2 $\mathrm{mm}$ dan $4 \mathrm{~mm}$ atau lebih. Sedangkan pada SNI 8210, persyaratan fragmentasi dibedakan berdasarkan penggunaan sebagai kaca depan dan selain kaca depan atau panel. Persyaratan kaca pengaman diperkeras sebagai kaca depan dibagi lagi dalam pembagian zona kaca FI, FII dan FIII. Selain itu persyaratan jumlah fragmen pada SNI 8210 dan JIS 3213 juga terdapat perbedaan, salah satunya adalah sebagai berikut :

- JIS 3213, kaca dengan tebal $4 \mathrm{~mm}$ atau lebih.

Jumlah fragmen dalam daerah $50 \mathrm{~mm} \times 50$ $\mathrm{mm}$ harus 40 buah atau lebih. Selanjutnya, ketika bagian yang mencakup kurang dari 40 buah fragmen terjadi, jumlah fragmen dalam daerah $100 \mathrm{~mm}$ x $100 \mathrm{~mm}$ termasuk 
bagian yang mencakup kurang dari 40 buah fragmen tersebut harus 160 buah atau lebih

- SNI 8210, kaca depan - zona FI.

Jumlah fragmen dalam luasan $5 \mathrm{~cm} \times 5 \mathrm{~cm}$ tidak kurang dari 40 dan tidak lebih dari 350. Dalam hal jumlah fragmen dalam luasan 5 $\mathrm{cm} \times 5 \mathrm{~cm}$ kurang dari 40, hal ini harus diterima jika jumlah fragmen dalam luasan $10 \mathrm{~cm} \times 10 \mathrm{~cm}$ (termasuk luasan $5 \mathrm{~cm} \times 5$ $\mathrm{cm}$ tersebut di atas) tidak kurang dari 160 .

Pada SNI 8210, diberikan batas maksimal fragmen tidak lebih dari 350 untuk luasan $5 \mathrm{~cm}$ x $5 \mathrm{~cm}$, sedangkan pada JIS 3213 tidak diatur batas maksimalnya. Pemberlakuan syarat mutu fragmentasi pada kaca pengaman diperkeras sangat penting, karena pecahan kaca baik akibat tumbukan benda tajam maupun yang lainnya harus tidak melukai penumpang karena terdapat batasan minimal dan maksimal fragmentasi pada luasan tertentu. Jika fragmen kaca kurang dari batas minimal, maka fragmen kaca menjadi besar dan beresiko melukai penumpang. Jika fragmen kaca melebihi batas maksimal, maka fragmen kaca menjadi sangat halus, hal ini juga dapat beresiko melukai. Dengan adanya SNI sebagai standar mutu minimum produk, sangat berperan penting bagi jaminan mutu keamanan dan keselamatan produk, khusunya pada kaca pengaman.

Berdasarkan pada Tabel 1 dan Tabel 2, maka kemungkinan persyaratan mutu yang dapat menginterpretasikan kebutuhan visual dan mekanik dari peraturan perkerataapian adalah sebagai berikut

Tabel 3 - Rekomendasi syarat mutu standar kereta api

\begin{tabular}{|c|c|c|c|c|c|}
\hline \multirow[b]{2}{*}{ No } & \multirow[b]{2}{*}{ Parameter } & \multirow[b]{2}{*}{ Syarat mutu } & \multicolumn{3}{|c|}{ Jenis Kaca } \\
\hline & & & $\begin{array}{c}\text { Kaca pengaman } \\
\text { berlapis }\end{array}$ & $\begin{array}{c}\text { Kaca pengaman } \\
\text { diperkeras }\end{array}$ & $\begin{array}{c}\text { Kaca pengaman } \\
\text { isolasi }\end{array}$ \\
\hline \multirow[t]{2}{*}{1.} & Dimensi & $\begin{array}{l}\text { Toleransi panjang, } \\
\text { lebar dan tebal }\end{array}$ & $\mathrm{v}$ & $\mathrm{v}$ & $\mathrm{v}$ \\
\hline & & Kerataan & $\mathrm{V}$ & $\mathrm{v}$ & $\mathrm{v}$ \\
\hline \multirow[t]{11}{*}{2.} & Visual & Sifat tampak & $\mathrm{v}$ & $\mathrm{v}$ & $\mathrm{v}$ \\
\hline & & Transmisi cahaya & $\mathrm{v}$ & - & \\
\hline & & Distorsi optik & $\mathrm{V}$ & - & \\
\hline & & Abrasi & $\mathrm{V}$ & - & \\
\hline & & Ketahanan radiasi & $\mathrm{v}$ & - & \\
\hline & & $\begin{array}{l}\text { Ketahanan } \\
\text { kelembaban }\end{array}$ & $\mathrm{v}$ & - & $\mathrm{v}$ \\
\hline & & $\begin{array}{l}\text { Daya tahan } \\
\text { terhadap } \\
\text { percepatan }\end{array}$ & - & - & $\mathrm{v}$ \\
\hline & & Karakteristik termal & - & - & $\mathrm{v}$ \\
\hline & & Secondary image & - & V & \\
\hline & & Titik embun & - & & $\mathrm{v}$ \\
\hline & & $\begin{array}{ll}\text { Visibilitas } & \text { sisa } \\
\text { setelah pecah } & \end{array}$ & $\mathrm{v}$ & - & - \\
\hline \multirow[t]{4}{*}{3.} & Mekanik & Ketahanan bentur & & - & - \\
\hline & & $\begin{array}{l}\text { Ketahanan } \\
\text { benturan kepala } \\
\text { boneka uji (manikin) }\end{array}$ & $\mathrm{v}$ & - & - \\
\hline & & Fragmentasi & - & $\mathrm{v}$ & - \\
\hline & & $\begin{array}{l}\text { Ketahanan suhu } \\
\text { tinggi }\end{array}$ & $\mathrm{v}$ & - & - \\
\hline
\end{tabular}

Tabel 3 telah merangkum parameter syarat mutu yang dapat digunakan sebagai acuan dalam penyusunan syarat mutu standar kereta api. Syarat mutu dimensi sangat penting untuk menjamin bahwa dimensi produk telah sesuai dengan toleransi yang diizinkan sesuai dengan standar yang telah ditetapkan. Sedangkan parameter visual ditetapkan dalam standar ini untuk menjamin bahwa peraturan pada Tabel 2 dapat terakomodir, sehingga persyaratan bagi masinis untuk melihat sinyal, tanda dan marka serta kenyamanan penerangan bagi 
penumpang dan kebutuhan untuk melihat pemandangan dari jendela dapat terakomodir dengan baik melalui parameter yang terkait visual seperti sifat tampak, transmisi cahaya, distorsi optik, abrasi dan lain-lain. Untuk parameter mekanik yang merupakan titik kritis dalam standar kaca pengaman ini, telah diakomodir dengan persyaratan mutu ketahanan bentur, ketahanan benturan kepala boneka uji (manikin) dan fragmentasi serta tambahan lain berupa ketahanan suhu tinggi, spalling, ketahanan terhadap api, ketahanan terhadap benturan berulang dari partikel kecil (gravelling). Dalam penyusunan standar harus mempertimbangkan berbagai aspek, salah satunya adalah kebutuhan penyelenggaraan standar tersebut. Dengan kebutuhan nasional Indonesia terkait kasus pelemparan dengan batu, maka syarat mutu ketahanan bentur dan fragmentasi harus menjadi perhatian utama sehingga dapat mengakomodir kebutuhan tersebut.

\section{KESIMPULAN}

Dengan melihat perbandingan standar kaca pengaman untuk kereta yang telah diimplementasikan di Jepang dan Eropa serta SNI kaca pengaman untuk kendaraan bermotor, telah memberikan gambaran bagi penyusunan standar kaca pengaman untuk kereta api. Parameter dimensi, visual dan mekanik menjadi dasar bagi penyusunan standar tersebut yang juga berdasarkan pada peraturan perkeretaapian yang berlaku. Kajian dan penelitian selanjutnya mengenai masingmasing parameter syarat mutu harus dilakukan untuk menetapkan standar yang sesuai dengan kebutuhan nasional. Peran serta dari seluruh pemangku kepentingan untuk bekerja sama mewujudkan standar pengaman untuk kaca kereta ini sangat penting. Dengan peran serta seluruh pihak, dampak yang diharapkan dengan adanya standar ini adalah jaminan keselamatan dan keamanan bagi seluruh pengguna sarana kereta api di indonesia semakin baik dan meningkat.

\section{UCAPAN TERIMA KASIH}

Ucapan terima kasih kami sampaikan pada Balai Besar Keramik, Asosiasi Kaca Lembaran dan Pengaman Indonesia, PT.KAI serta Badan Standardisasi Nasional yang telah menjalin kerjasama untuk penyusunan standar kaca pengaman untuk kereta sehingga penulis dapat menyusun kajian ini berdasarkan sumber standar yang tersedia.

\section{DAFTAR PUSTAKA}

Badan Pusat Statistik. (2017). Jumlah Penumpang Kereta Api, 2006-2019 (Ribu Orang). https://doi.org/10.1055/s-20081040325

Badan Standardisasi Nasional. (2005a). SNI 15-0048-2005, Kaca pengaman diperkeras untuk kendaraan bermotor.

Badan Standardisasi Nasional. (2005b). SNI 15-1326-2005, Kaca pengaman berlapis untuk kendaraan bermotor.

Badan Standardisasi Nasional. (2011a). SNI ISO 12543-1:2011, Kaca untuk bangunan - Kaca berlapis dan kaca pengaman berlapis - Bagian 1 : Definisi dan deskripsi komponen.

Badan Standardisasi Nasional. (2011b). SNI ISO 12543-2, Kaca untuk bangunan Kaca berlapis dan kaca pengaman berlapis - Bagian 2: Kaca pengaman berlapis.

Badan Standardisasi Nasional. (2011c). SNI ISO 12543-3, Kaca untuk bangunan Kaca berlapis dan kaca pengaman berlapis - Bagian 3: Kaca berlapis.

Badan Standardisasi Nasional. (2011d). SNI ISO 12543-4, Kaca untuk bangunan Kaca berlapis dan kaca pengaman berlapis - Bagian 4: Metode uji daya tahan.

Badan Standardisasi Nasional. (2017). SNI ISO 12540:2017, Kaca untuk bangunan Kaca pengaman soda kapur silikat diperkeras.

Badan Standardisasi Nasional. (2018a). SNI 47:2018, Kaca lembaran.

Badan Standardisasi Nasional. (2018b). SNI 8210:2018, Kaca pengaman untuk kendaraan bermotor.

British Standard. (2007). BS EN 15152 Railway Applications - Front Windscreen for Train Cabs.

Japanese Standard Association. (n.d.). JIS $R$ 3213:2018, Safety Glass for Railway Rolling Stock.

Kementerian Hukum dan HAM. Peraturan Pemerintah Republik indonesia Nomor 72 Tahun 2009 Tentang Lalu Lintas dan Angkutan Kereta Api.

Kementerian Perhubungan. Peraturan Menteri Perhubungan Republik Indonesia Nomor: PM 153 Tahun 2016 Tentang Standar Spesifikasi Teknis Lokomotif Sarana Perkeretaapian.

Kementerian Perhubungan. Peraturan Menteri Perhubungan Nomor: KM. 44 Tahun 2010 Tentang Standar Spesifikasi Teknis 


\section{Peralatan Khusus.}

Kementerian Perhubungan. Peraturan Menteri Perhubungan Republik Indonesia Nomor: PM. 47 Tahun 2014 Standar Pelayanan Minimum untuk Angkutan Orang dengan Kereta.

Kementerian Perhubungan. Peraturan Menteri Perhubungan Republik Indonesia Nomor: PM. 24 Tahun 2015 Standar Keselamatan Perkeretaapian.

Kementerian Perhubungan. Peraturan Menteri Perhubungan Republik Indonesia Nomor: PM. 175 Tahun 2015 Standar Spesifikasi Teknis Kereta Kecepatan Norma Dengan Penggerak Sendiri.

Komite Nasional Keselamatan Transportasi. (2015). Laporan Hasil Investigasi Kecelakaan Kereta Api, KRL 1156 Menumbur KRL 1154 di St. Juanda KM 4+300 DAOP I Jakarta. http://knkt.dephub.go.id/knkt/ntsc railway /Report/baru/2015/KNKT.15.09.04.02.pdf

M.,Yudi Y., et.al. (2012). Sistem Keamanan Kereta Api dengan Menggunakan GPS sebagai Pemantau Jalur dan Posisi Sarana. Prosiding Insinas 2012.

Okenews. (2018). 28 Kasus Pelemparan Batu ke KA di Cirebon, Pelaku Mayoritas Pelajar SMP _ Okezone News. Retrieved June $\quad \overline{13}, \quad 2019, \quad$ from https://news.okezone.com/read/2018/07/ 11/525/1920929/28-kasus-pelemparanbatu-ke-ka-di-cirebon-pelaku-mayoritaspelajar-smp

Pramyastiwi, D., Hardjanto, I., \& Said, A. (2013). Perkembangan Kualitas Pelayanan Perkeretaapian Sebagai Angkutan Publik Dalam Rangka Mewujudkan Transportasi Berkelanjutan (Studi Pada PT Kereta Api Indonesia Daerah Operasi 8 Surabaya). Jurnal Administrasi Publik (JAP), 1(3), 61-69.

Republika. (2017). Tiga Penumpang Luka dan 20 Kaca KA Serayu Pecah. Retrieved June 13, 2019, from https://nasional.republika.co.id/berita/nasi onal/daerah/17/03/24/onb5f4366-tigapenumpang-luka-dan-20-kaca-ka-serayupecah

Rosida, B., Herijanto, W. (2014). Analisis Kinerja Operasi Kereta Api Sriwedari Ekspress Jurusan Solo-Yogya. Jurnal Teknik POMITS Vol. 3, No.1.

United Nations. (2012). Addendum 42: Regulation No. 43 Revision 3, Uniform provisions concerning the approval of safety glazing materials and their installation on vehicles.

Yustikasari, Malinda. (2011). Manajemen
Sarana dan Prasarana Perkeretaapian di PT. Kereta Api Indonesia (Persero) Daerah Operasi (Daop) VII Madiun. Skripsi. 
Prosiding PPIS 2019 - Semarang, 11 Oktober 2019, Hal 251-260 